AUTHOR CORRECTION OPEN

\title{
Author Correction: Identification of donor microbe species that colonize and persist long term in the recipient after fecal transplant for recurrent Clostridium difficile
}

Ranjit Kumar ${ }^{1}$, Nengjun Yi ${ }^{2}$, Degui Zhi' ${ }^{2}$, Peter Eipers ${ }^{3}$, Kelly T. Goldsmith ${ }^{4}$, Paula Dixon ${ }^{5}$, David K. Crossman ${ }^{4}$, Michael R. Crowley ${ }^{4}$, Elliot J. Lefkowitz ${ }^{1,6}$, J. Martin Rodriguez ${ }^{5}$ and Casey D. Morrow ${ }^{3}$

npj Biofilms and Microbiomes (2017)3:29; doi:10.1038/s41522-017-0037-y

Correction to: npj Biofilms and Microbiomes (2017); doi:10.1038/ s41522-017-0020-7

The affiliation details were incorrect in this article. The correct affiliation details are given below:

${ }^{1}$ Biomedical Informatics, Center for Clinical and Translational Sciences, University of Alabama at Birmingham, Birmingham, AL 35294, USA; ${ }^{2}$ Department of Biostatistics, University of Alabama at Birmingham, Birmingham, AL 35294, USA; ${ }^{3}$ Department of Cell, Developmental and Integrative Biology, University of Alabama at Birmingham, Birmingham, AL 35294, USA; ${ }^{4}$ Department of Genetics and Heflin Center for Genomic Science, University of Alabama at Birmingham, Birmingham, AL 35294, USA; ${ }^{5}$ Department of Medicine, Division of Infectious Diseases, University of Alabama at Birmingham, Birmingham, AL 35294, USA and ${ }^{6}$ Department of Microbiology, University of Alabama at Birmingham, Birmingham, AL 35294, USA.

In addition, this article was originally published without the accompanying supplementary tables. This file is now available in the HTML version of the article; the PDF was correct from the time of publication.

\begin{abstract}
(c) (i) Open Access This article is licensed under a Creative Commons Attribution 4.0 International License, which permits use, sharing, adaptation, distribution and reproduction in any medium or format, as long as you give appropriate credit to the original author(s) and the source, provide a link to the Creative Commons license, and indicate if changes were made. The images or other third party material in this article are included in the article's Creative Commons license, unless indicated otherwise in a credit line to the material. If material is not included in the article's Creative Commons license and your intended use is not permitted by statutory regulation or exceeds the permitted use, you will need to obtain permission directly from the copyright holder. To view a copy of this license, visit http://creativecommons. org/licenses/by/4.0/.
\end{abstract}

(c) The Author(s) 2017

\footnotetext{
${ }^{1}$ Biomedical Informatics, Center for Clinical and Translational Sciences, University of Alabama at Birmingham, Birmingham, AL 35294, USA; ${ }^{2}$ Department of Biostatistics, University of Alabama at Birmingham, Birmingham, AL 35294, USA; ${ }^{3}$ Department of Cell, Developmental and Integrative Biology, University of Alabama at Birmingham, Birmingham, AL 35294, USA; ${ }^{4}$ Department of Genetics and Heflin Center for Genomic Science, University of Alabama at Birmingham, Birmingham, AL 35294, USA; ${ }^{5}$ Department of Medicine, Division of Infectious Diseases, University of Alabama at Birmingham, Birmingham, AL 35294, USA and ${ }^{6}$ Department of Microbiology, University of Alabama at Birmingham, Birmingham, AL 35294, USA
}

Correspondence: Ranjit Kumar (rkumar@uab.edu) or Casey D. Morrow (caseym@uab.edu)

Published online: 03 November 2017 